J. Clin. Chem. Clin. Biochem.

Vol. 19, 1981, pp. 139-143

\title{
Improved Enzymatic Method for Determining Mannitol and its Application to Dog Serum after Mannitol Infusion
}

\author{
By C. H. Blomquist
}

Department of Obstetrics and Gynecology, St. Paul-Ramsey Medical Center, St. Paul, and University of Minnesota Medical School, Minneapolis, MN,

\section{B. D. Snyder}

Department of Neurology, St. Paul-Ramsey Medical Center, St. Paul, and University of Minnesota Medical School, Minneapolis, $M N$, and

\section{W. G. Niehaus}

Department of Biochemistry and Nutrition, Virginia Polytechnic Institute and State University, Blacksburg, VA

(Received April 24/September 29, 1980)

Summary: An enzymatic method for mannitol quantitation has been developed. Its application in determining mannitol levels in serum samples from dogs after mannitol infusion is illustrated.

The method is based on the spectrophotometric measurement of the initial rate of NADH formation in the reaction between mannitol and NAD catalyzed by mannitol dehydrogenase. A linear relationship between initial rates and mannitol concentration is seen between $17 \mu \mathrm{mol} / 1$ and $6.7 \mathrm{mmol} / 1$ mannitol. From the extent of dilution of the serum sample in the assay this corresponds to serum levels of 0.5 to $200 \mathrm{mmol} / \mathrm{l}$.

Because of the high degree of substrate specificity of mannitol dehydrogenase and the extensive dilution of the serum sample in the assay reaction mixture, serum proteins and glucose do not interfere with the reaction. As a result, pre-treatment of samples to remove glucose and deproteinization are unnecessary.

\section{Verbesserte enzymatische Methode zur Bestimmung von Mannit und ihre Anwendung auf Serum vom Hund nach Mannitinfusion}

Zusammenfassung: Eine Methode zur quantitativen Bestimmung von Mannit wurde entwickelt. Ihre Anwendung zur Bestimmung der Mannitkonzentration in Serumproben vom Hund nach Mannitinfusion wird dargestellt.

Die Methode beruht auf der spektrophotometrischen Messung der Anfangsgeschwindigkeit der NADH-Bildung in der durch Mannitdehydrogenase katalysierten Reaktion zwischen Mannit und NAD. Eine lineare Beziehung besteht zwischen den Anfangsgeschwindigkeiten und Mannitkonzentrationen zwischen $17 \mu \mathrm{mol} / \mathrm{l}$ und 6,7 mmol/l. Dies entspricht unter Berücksichtigung der Verdünnung der Serumprobe im Bestimmungsansatz Konzentrationen von 0,5$200 \mathrm{mmol} / 1$ Serum.

Wegen der hohen Substratspezifität von Mannitdehydrogenase und der erheblichen Verdünnung der Serumprobe im Beștimmungsansatz stören Serumproteine und Glucose die Reaktion nicht. Daher ist eine Vorbehandlung der Proben zur Entfermung von Glucose und Enteiweißung nicht erforderlich.

\section{Introduction}

There is a large body of evidence to document the effects of mannitol on vascular resistance and plasma osmotic pressure in experimental animals $(1,2)$. The infusion of mannitol has been prescribed in a wide variety of clinical situations including drug intoxication, refractory edema, oliguric renal failure and increased intra-ocular pres- sure $(1,2)$, cerebral edema $(3,4)$ and post-trauma respiratory distress (5).

However, relationships between mannitol dosage and rate of delivery, plasma osmotic pressure and therapeutic effectiveness have been difficult to establish in animal studies and during the course of clinical treatment. One reason for this has been the lack of data on manni- 
tol pharmacokinetics. This latter problem could be alleviated by the development of a rapid and relatively simple method for measuring serum mannitol levels.

A colorimetric method based on the measurement of formaldehyde formed by periodic acid oxidation of mannitol has been used $(6,7)$ and, more recently, gasliquid chromatographic procedures have been developed (8-13). However, in the majority of cases, the application of these methods to biological samples is technically rather difficult and time consuming, requiring sample deproteinization and, in the latter procedures, the conversion of mannitol to a volatile derivative suitable for chromatography (8-10).

It has been known for a number of years that a highly specific mannitol dehydrogenase (mannitol: nicotinamide adenine dinucleotide 2-oxidoreductase; EC 1.1.1. 67) from bacteria will catalyze the NAD-linked oxidation of mannitol to fructose and $\operatorname{NADH}(14,15)$. Horecker (14) described a mannitol assay based on the colorimetric determination of the fructose formed as a reaction product. A sensitivity down to $0.5 \mathrm{mmol} / \mathrm{l} \mathrm{manni-}$ tol was attainable but a sample incubation time of $3 \mathrm{~h}$ was required, followed by a color reaction for fructose.

Since the Michaelis constant for mannitol is $40-60$ $\mathrm{mmol} / \mathrm{l}(14,15)$, the utility of spectrophotometric assays based on the complete oxidation of mannitol to fructose may be limited by excessive time requirements or the need for large amounts of enzyme. Also, partially purified samples of mannitol dehydrogenase contain NADH oxidase acitivity (W. G. Niehaus, unpublished work) thus eliminating the possibility of quantitating mannitol on the basis of total mannitol-dependent NADH formation. However, at mannitol levels significantly below the Michaelis constant the initial rate of NADH formation is linearly dependent on mannitol concentration and even in the presence of low levels of NADH oxidase activity, an initial velocity can be easily determined. We describe here a method based on this principle.

\section{Materials and Methods}

\section{Materials}

Coomassie Brilliant Blue G, $D$-mannitol, bicine (N,N-bis (2-hydroxyethyl)-glycine), and trishydroxymethyl aminomethane were purchased from Sigma Chemical Co., St. Louis, Mo. NAD was from P-L Biochemicals, Inc., Milwaukee, WI. Celite 545 was from Sargent-Welch Scientific Co., Skokie, IL and diethylaminoethyl-cellulose (DE-23) was a product of Whatman Inc., Clifton, $\mathrm{NJ}$.

\section{Protein assay}

Protein was measured by the method of Bradford (16) based on the binding of Coomassie Brilliant Blue G. Bovine serum albumin was used as the protein standard.

\section{Serum glucose determinations}

The levels of glucose in dog serum samples were measured in the Clinical Chemistry Laboratories of St. Paul-Ramsey Medical Center by an automated glucose oxidase method.

\section{Assay of mannitol dehydrogenase activity}

NADH formation was recorded at $340 \mathrm{~nm}$ on a Gilford Model 240 spectrophotometer fitted with a Model 6040 recorder. Reactions were run at room temperature.

For routine assays during enzyme preparation reaction mixtures were prepared by combining $2.5 \mathrm{ml}$ of $0.5 \mathrm{~mol} / 1$ mannitol in 50 $\mathrm{mmol} / \mathrm{l}$ trishydroxymethyl aminomethane, $\mathrm{pH} 8.6$, and $0.2 \mathrm{ml}$ of $10 \mathrm{mmol} / \mathrm{l}$ NAD. Reaction was started by the addition of an aliquot of enzyme solution sufficient to produce an absorbance change of approximately 0.05 per minute. A unit of mannitol dehydrogenase activity catalyzed the reduction of one micromole of NAD in one minute.

\section{Preparation of mannitol dehydrogenase}

Lactobacillus brevis (ATCC 367) was grown as described by Horecker (14) and cells were collected by batch centrifugation. Details of a typical procedure are given below and recovery data and specific activities are summarized in table 1.

From $30 \mathrm{l}$ of culture medium we obtained $50 \mathrm{~g}$ wet weight of cells. These were suspended in $200 \mathrm{ml}$ of buffer composed of $1 \mathrm{mmol} / 1 \mathrm{EDTA}, 1 \mathrm{mmol} / 12$-mercaptoethanol and $25 \mathrm{mmol} / 1$ potassium phosphate, pH 6.8 (buffer A).

Cells were disrupted by sonication for $15 \mathrm{~min}$ in the presence of $250 \mathrm{~g}$ of glass beads. The temperature was maintained below $15^{\circ} \mathrm{C}$ during sonication. All subsequent purification steps were carried out at $4^{\circ} \mathrm{C}$.

After centrifugation of the sonicate at $10000 \mathrm{~g}$ for $30 \mathrm{~min}$ the clear extract, containing 24000 units of mannitol dehydrogenase activity, was applied to a $40 \times 100 \mathrm{~mm}$ column of DE-23 which had been equilibrated at pH 6.8 with buffer $\mathrm{A}$. The column was washed with $200 \mathrm{ml}$ of buffer $A$ and mannitol dehydrogenase activity then eluted with a linear salt gradient prepared from $200 \mathrm{ml}$ each of buffer $A$ and buffer $A$ plus $0.5 \mathrm{~mol} / 1$ $\mathrm{KCl}$. Acitve fractions were pooled (16000 units) and subjected to further purification by ammonium sulfate gradient solubilization $(17,18)$, as follows.

The pooled eluate, $250 \mathrm{ml}$, was mixed with $10 \mathrm{~g}$ of Celite 545 and solid ammonium sulfate added to a final concentration of $3 \mathrm{~mol} / \mathrm{l}$. The resultant slurry was stirred at $4^{\circ} \mathrm{C}$ for several hours and then poured into a glass column. After the Celite 545-protein slurry had settled into a column, it was washed with 50$100 \mathrm{ml}$ of $3 \mathrm{~mol} / \mathrm{l}$ ammonium sulfate. Mannitol dehydrogenase activity was then eluted by solubilization in a linear reverse gradient of ammonium sulfate from $3 \mathrm{~mol} / 1$ to $1 \mathrm{~mol} / \mathrm{l}$. Active fractions were pooled to give 15000 units of activity with a specific activity of 55 units per mg of protein. This specific activity was $75 \%$ of that reported by Horecker (14) for the $3 \times$-crystallized enzyme. The preparation also contains a trace of NADH oxidase activity. Enzyme was stable for at least eight months.

\section{Mannitol infusion and preparation of serum samples}

For mannitol infusion studies dogs were fasted overnight. Then, under pentobarbital anesthesia $(30 \mathrm{mg} / \mathrm{kg}$ body weight), the animals were injected intravenously with a single dose of mannitol (0.5-2.0 g/ $\mathrm{kg}$ body weight given as $200 \mathrm{~g} / 1$ mannitol solution).

Tab. 1. Preparation of mannitol dehydrogenase. Experimental details are given under Materials and Methods.

\begin{tabular}{lrrrr}
\hline & $\begin{array}{l}\text { Total } \\
\text { protein } \\
\text { (mg) }\end{array}$ & $\begin{array}{l}\text { Total } \\
\text { activity } \\
(\mathrm{U})\end{array}$ & $\begin{array}{l}\text { Specific } \\
\text { activity } \\
(\mathrm{U} / \mathrm{mg})\end{array}$ & $\begin{array}{l}\text { Recovery } \\
(\%)\end{array}$ \\
\hline $\begin{array}{l}10000 \mathrm{~g} \\
\text { supernate }\end{array}$ & 12000 & 24000 & 2.0 & 100 \\
$\begin{array}{l}\text { DE-23 column } \\
\text { fractions }\end{array}$ & 800 & 16000 & 20.0 & 67 \\
$\begin{array}{l}\text { Ammonium sulfate } \\
\text { gradient fractions }\end{array}$ & 273 & 15000 & 55.0 & 62 \\
\hline
\end{tabular}


The injection time was less than $15 \mathrm{~s}$. Blood samples were drawn at $30 \mathrm{~s}$ after the injection and at intervals thereafter. These were centrifuged and the supernatant serum fractions stored frozen until analyzed. Prior to assay the thawed samples were clarified by a $10 \mathrm{~min}$ centrifugation at $1800 \mathrm{~g}$.

\section{Assay of serum mannitol}

A stock enzyme reagent solution composed of enzyme (5-25 $\mathrm{mg} / 1$ protein), $0.12 \mathrm{~mol} / 1$ bicine, $\mathrm{pH} 9.0$, an optimal $\mathrm{pH}$ for mannitol oxidation $(14,15)$, and $1.2 \mathrm{mmol} / 1$ NAD was prepared and incubated at room temperature for 30-45 min. During this incubation background reactions yielding NADH in the absence of added mannitol were completed such that no further change in absorbance at $340 \mathrm{~nm}$ was observed in the absence of added serum or mannitol standard. The decrease in NAD during this pre-incubation was $2-3 \%$ or less of the total present.

Aliquots $(2.9 \mathrm{ml})$ of this reagent solution were added to cuvettes which were then placed in the sample chamber of the spectrophotometer. Absorbance at $340 \mathrm{~nm}$ was recorded for $2-3$ minutes after which reaction was started by the addition of $100 \mu l$ of serum or mannitol standard. The change on absorbance was recorded for 3-5 minutes. Initial velocities were determined from tangents constructed to the first 2-3 minutes of the reaction progression curves.

\section{Results}

\section{Standard curves}

Standard curves for two ranges of mannitol concentratons, $0.017-0.833$ and $0.33-6.67 \mathrm{mmol} / 1$, are shown in figure 1. The initial rate of $\mathrm{NADH}$ formation was a linear function of mannitol concentration up to at least 6.67 $\mathrm{mmol} / 1$. A lower limit of $17 \mu \mathrm{mol} / \mathrm{l}$ was detectable.

Considering the 40 -fold dilution of the serum sample in the assay, the data in figure 1 are equivalent to a range of serum mannitol levels of $0.5-200 \mathrm{mmol} / 1$. This lower value of $0.5 \mathrm{mmol} / 1$, adequate for our purposes, was attained with a recorder full-scale range of $0.0-0.3$ absorbance unit. Further sensitivity could be achieved by reducing this to $0.0-0.1$ and/or increasing the volume of serum analyzed.

No reaction could be detected with serum samples to which no mannitol had been added. Mannitol is detectable in only trace amounts in normal human serum (10, 13) and our results are consistent with a similar conclusion with regard to dog serum.

\section{Effects of serum on mannitol quantitation}

Mannitol dehydrogenase exhibits a high degree of substrate specificity and does not react with various polyol compounds which might be present in serum, such as glucose, sorbitol, inositol or xylitol $(14,15)$. However, glucose was present at $4.3-5.7 \mathrm{mmol} / \mathrm{l}$ in the serum samples used in this study and the extent to which compounds of this type might bind to the active site of the enzyme and inhibit reaction has not been extensively investigated. To consider this question standärds were assayed in the presence and absence of added serum. As shown in figure 2 the mannitol standard curve was not affected by serum at the level used in the usual assay

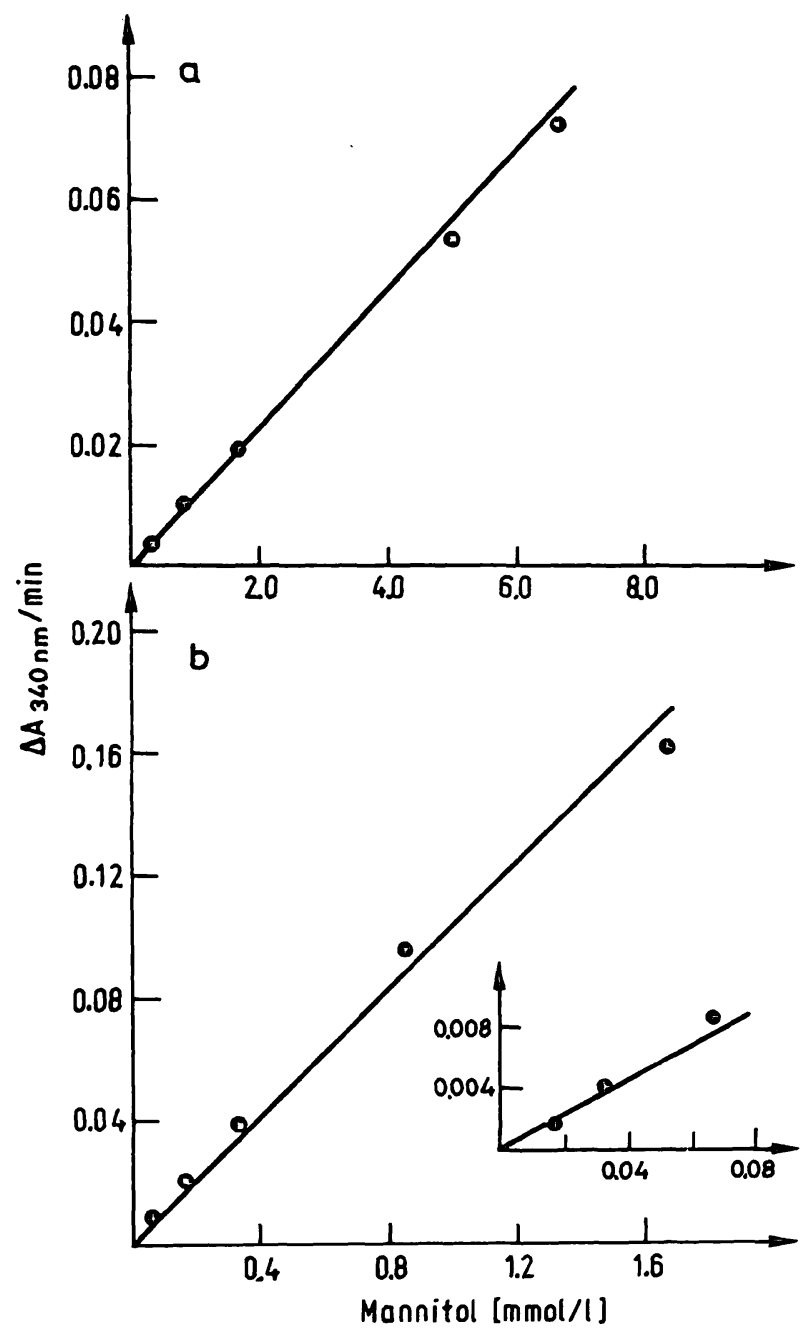

Fig. 1. Standard curves. Assays were done as described under Materials and Methods.

a) Mannitol dehydrogenase was at $5 \mathrm{mg} / 1$ protein. Data points are mean values of three determinations each at $0.33,0.83,1.67,5.00$ and $6.67 \mathrm{mmol} / 1$ mannitol. The slope of the line is based on the mean value of $\Delta \mathbf{A} \cdot \mathrm{min}^{-1} \cdot \mathrm{mmor}^{-1} \cdot \mathrm{l}(\mathrm{n}=15)$ and equals 0.0114 . The standard deviation is 0.0013 and the coefficient of variation is $11.4 \%$.

b) Mannitol dehydrogenase was at $22 \mathrm{mg} / \mathrm{l}$ protein. Data points are mean values of $2-5$ replicates at 0.033 , $0.067,0.333$ and $0.833 \mathrm{mmol} / 1$ mannitol. The slope of the lines in the figure and inset is based on a mean value for $\Delta A \cdot \mathrm{min}^{-1} \cdot \mathrm{mmol}^{-1} \cdot 1$ of $0.1182(\mathrm{n}=17)$. The standard deviation is 0.0092 and the coefficient of variation equals $7.8 \%$. The data points in the inset are for $0.017,0.033$ and $0.067 \mathrm{mmol} / 1$ mannitol

mixture. Thus it is not necessary to deproteinize the serum or to attempt to remove glucose.

\section{Determination of mannitol added in vitro to serum obtained after mannitol infusion}

To estimate recovery, known amounts of mannitol were added to serum samples from dogs which had been previously infused with mannitol. Data are given in table 2 . The total amounts observed after the addition of mannitol were $86-100 \%$ of the calculated sums of mannitol present plus mannitol added. 


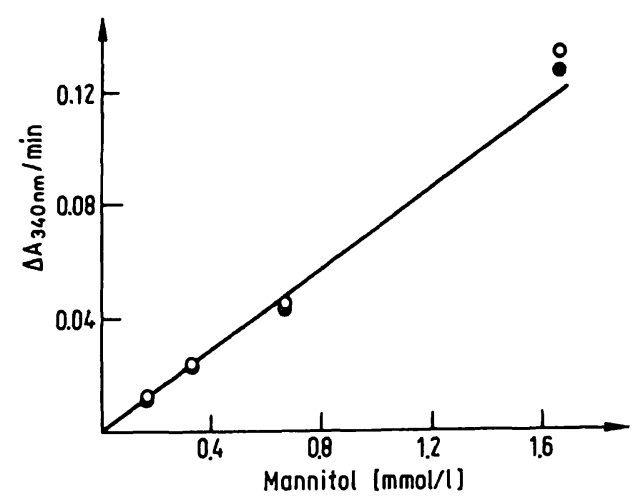

Fig. 2. Initial velocities observed with mannitol standards assayed in the presence and absence of serum. Reaction mixtures $(3.0 \mathrm{ml})$ contained $21 \mathrm{mg} / 1$ mannitol dehydrogenase and $0.1 \mathrm{ml}$ of dog serum $(\bullet)$ or water $(0)$ The line represents the average initial velocity of $0.071 \mathrm{l} \cdot \mathrm{mmol}^{-1} \cdot \mathrm{min}^{-1}$. The average deviation of duplicate assays was $5.7 \%$.

Tab. 2. Recovery of mannitol added to serum samples containing mannitol.

Assays were run as described unter Materials and Methods. Reaction mixtures of $3.0 \mathrm{ml}$ total volume contained 100 $\mu l$ of dog serum. The data are mean values \pm standard deviation for $\mathrm{n}$ determinations. $\mathrm{CV}=$ coefficient of variation.

\begin{tabular}{lcccc}
\hline Sample & $\begin{array}{l}\text { Mannitol } \\
\text { added } \\
\text { (mmol/l) }\end{array}$ & $\begin{array}{l}\text { Mannitol } \\
\text { observed } \\
\text { (mmol/l) }\end{array}$ & n & \multicolumn{1}{c}{$\begin{array}{l}\text { CV } \\
(\%)\end{array}$} \\
\hline 1 & 0 & $34.8 \pm 3.4$ & 2 & 9.7 \\
& 20 & $51.2 \pm 4.4$ & 2 & 8.6 \\
2 & 0 & $28.1 \pm 2.7$ & 2 & 9.6 \\
& 20 & $42.2 \pm 4.0$ & 2 & 9.5 \\
3 & 0 & $10.1 \pm 2.5$ & 2 & 24.7 \\
& 20 & $25.9 \pm 3.2$ & 2 & 12.3 \\
4 & 0 & $132.5 \pm 6.4$ & 8 & 4.8 \\
& 20 & $151.1 \pm 6.2$ & 8 & 4.1 \\
5 & 0 & $76.3 \pm 6.7$ & 7 & 8.7 \\
& 20 & $99.3 \pm 6.0$ & 9 & 6.0 \\
6 & 0 & $30.7 \pm 2.8$ & 8 & 9.1 \\
& 20 & $47.7 \pm 3.6$ & 7 & 7.5 \\
\hline
\end{tabular}

\section{Mannitol levels in dog serum following infusion}

The application of the method to following mannitol levels in dogs is illustrated in figure 3. Aliquots of $100 \mu \mathrm{l}$ were taken from serum samples drawn at intervals after mannitol injection. A maximum level was reached by 1 minute after the completion of the injection. The mannitol concentration decreased rapidly to approximately 50 $\%$ of this peak by $4-5$ minutes. It then decreased more slowly and was undetectable at $90 \mathrm{~min}$.

\section{Discussion}

Nasrallah \& Iber (19) used both a colorimetric method (6) and ${ }^{14} \mathrm{C}$-labeled mannitol to measure the distribution

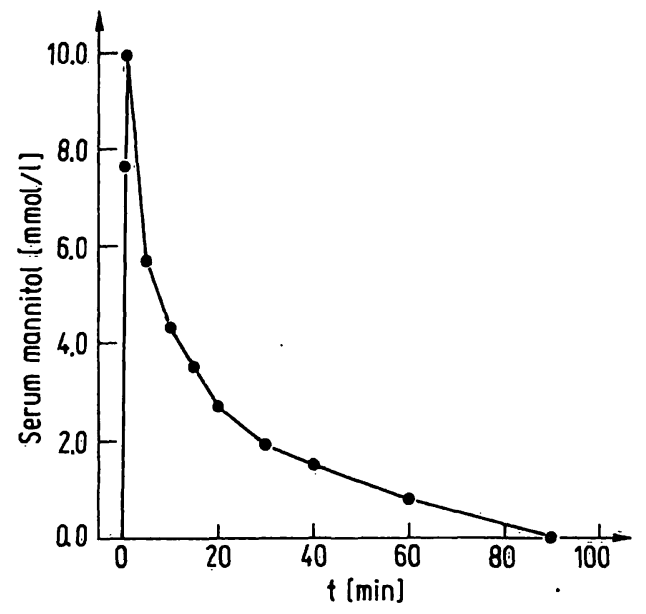

Fig. 3. Serum mannitol levels as a function of time after a single injection of mannitol.

Zero time was taken as the completion of the injection. Blood was drawn and samples analyzed as described under Materials and Methods.

Mannitol dehydrogenase was at $22 \mathrm{mg} / \mathrm{l}$ in the reaction mixtures.

in serum, urine and feces of mannitol ingested orally by human volunteers. They pointed out that both approaches have serious shortcomings; the colorimetric assay because of high and variable "blank" reactions and the isotopic method because one cannot distinguish mannitol from its metabolites unless a fractionation procedure is used.

Due to the high degree of substrate specificity expressed by mannitol dehydrogenase, problems of interfering substances and ambiguous identities of reactants are greatly reduced in an enzymatic assay. And, by making use of initial velocities, problems arising from the high Michaelis constant for mannitol and from side reactions catalyzed by other enzymes in the mannitol dehydrogenase preparations are largely avoided. Another important advantage of the enzymatic method as described here is the lack of a need for sample deproteinization or the removal of glucose.

The rate of NADH formation is linear for at least 2-3 minutes but deviates from linearity at later times due to the presence of an undefined NADH oxidase activity in the mannitol dehydrogenase preparations. Because of this the assay was based on initial velocities estimated by constructing tangents to the initial portions of the progression curves. However, fixed-time assays based on net increase in absorbance during the first five minutes of reaction have given results equivalent to those from initial velocity estimates.

As indicated in the description of the assay procedure under Materials and Methods, there is some NADH formation in reaction mixtures lacking serum or added mannitol but which contain buffer, NAD and enzyme. We do not know the basis for this reaction. One possible explanation is that an impurity in the NAD prepara- 
tion, such as ethanol $(20)$, is reacting with a second enzyme in the mannitol dehydrogenase preparation. In the procedure described here, this reaction will not contribute significantly to estimates of the initial rate of $\mathrm{NADH}$ formation if a pre-incubation is carried out.

The rapid increase and subsequent two-phase decrease in serum mannitol after a single injection (fig. 3) are consistent with previous data from human subjects $(7,19$, 21). The biphasic character of the decrease has been interpreted as due first to a rapid equilibration of the mannitol into the tissue space followed by a second, slower phase representing metabolism and excretion into the urine.

\section{References}

1. Gennari, F. J. \& Kassiver, J. P. (1974), New England J. Med. 291,714-720.

2. Feing, P. U. \& McCurdy, D. K. (1977), New England J. Med. 297, 1444-1454.

3. Hooshmand, H., Dove, J., Houff, S. \& Suter, C. (1969), Arch. Neurol. 21, 499-509.

4. Shenken, H. A., Goluboff, B. \& Haft, H. (1965) J. Neurosurg. 22, 563-568.

5. Powers, S. R., Jr., Shah, D., Ryon, D., Newell, J., Ralph, C., Scovill, W. \& Dutton, R. (1977), Ann. Surg. 185, 619-625.

6. Corcoran, A. C. \& Page, I. H. (1947), J. Biol. Chem. 170, $165-171$.

7. Dominguez, R., Corcoran, A. C. \& Page, I. H. (1947), J. Lab Clin. Med. 32, 1192-1202.

8. Oades, J. M. (1967), J. Chromatog. 28, 246-252.

9. Schweickhardt, C. (1978), this J. 16, 675-676.

10. Pitkänen, E. (1972), Clin. Chim. Acta 28, 221-230.

11. Manius, G., Mahn, F. P., Venturella, V. S. \& Senkowski, B. Z. (1972), J. Pharm. Sci. 61, 1831-1835.
With the enzymatic assay procedure described here, data as shown in figure 3 are obtained simply with readily available instrumentation. The analyses illustrated in figure 3 were completed within $90 \mathrm{~min}$.

\section{Acknowledgements}

This work was supported by grants from the St. Paul-Ramsey Medical Education and Research Foundation (B. D. S.) and the Herman Frasch Foundation (W. G. N.). The authors are grateful to Dr. E. M. Gregory for assistance with the bacterial culture and to Dr. $K$. Labrosse for the serum glucose determinations.
12. Sondack, D. L. (1975), J. Pharm. Sci. 64, 128-129.

13. Pitkänen, E., Bardy, A., Pasternach, A. \& Servo, C. (1976), Ann. Clin. Res. 8, 368-373.

14. Horecker, B. L., (1966), in "Methods in Enzymology", Vol. 9, p. 143-146 (Wood, W. A., ed.) Academic Press, New York.

15. Yamanaka, K. (1975), in "Methods in Enzymology", Vol. 41, p. 138-142 (Wood, W. A., ed.) Academic Press, New York.

16. Bradford, M. M. (1976), Anal. Biochem. 72, 248-254.

17. King, T. P. (1972), Biochemistry 11, 367-371.

18. Blomquist, C. H., Kotts, C. E. \& Hakanson, E. Y. (1978), Arch. Biochem. Biophys. 186, 35-41.

19. Nasrallah, S. M. \& Iber, F. L. (1969), Am. J. Med. Sci. 258, 80-88.

20. Bergmeyer, H. U. (1965), Methods of Enzymatic Analysis, 1st ed. p. 1010, Verlag Chemie, Weinheim/Bergstr.

21. Wick, A., Morita, T. N. \& Joseph, L. (1954), Proc. Soc. Exp. Biol. Med. 32, 1192-1202.
Dr. Charles H. Blomquist

Department of Obstetrics and Gynecology

St. Paul-Ramsey Medical Center

St. Paul, Minnesota 55101

U.S.A. 
. 